\title{
PENGARUH LAMA PENYIMPANAN KANTONG DARAH TERHADAP KADAR HEMOGLOBIN PADA KOMPONEN WHOLE BLOOD DI UNIT DONOR DARAH PMI KOTA PALANGKA RAYA
}

\author{
The Effect Storage Of Blood Bags on Hemoglobin Levels \\ In The Unit Donor Darah PMI Palangka Raya
}

\author{
Windya Nazmatur Rahmah ${ }^{\text {* }}$ \\ Adinda Chairunnissa ${ }^{2}$ \\ *Universitas Muhammadiyah \\ Palangkaraya, Palangka Raya, Indonesia \\ 2Universitas Muhammadiyah \\ Palangkaraya, Palangka Raya, Indonesia \\ *email: windy.nazmatur@gmail.com
}

\section{Kata Kunci:}

Penyimpanan Kantong Darah,

Hemoglobin, Whole Blood

\section{Keywords:}

Storage Blood Bags, Hemoglobin, Whole Blood

\begin{abstract}
Abstrak
Kadar hemoglobin digunakan sebagai syarat penentu terapi transfuse darah terhadap pasien anemia. Sebelum transfuse darah pada awalnya disimpan dalam kantong yang mengandung antokoagulan CPDA-I dengan masa simpan 35 hari pada suhu $2-6^{\circ} \mathrm{C}$ dengan sistem First In First Out. Tujuan penelitian ini adalah mengetahui pengaruh penyimpanan kantong darah donor pada penyimpanan hari-3 dan hari-5 di Unit Donor Darah PMI Kota Palangkaraya sehingga transfuse efektif dilakukan untuk menaikan kadar hemoglobin pasien. Penelitian ini dilakukan dengan metode deskriptif dengan desain penelitian Regensi Linear. Sampel yang digunakan yaitu kantong darah whole blood yang diperoleh dengan teknik purposive sampling dengan jumlah sampel 30 kantong darah. Berdasarkan uji Regression Linear pada kantong darah whole blood didapatkan $\mathrm{p}<0,05$ yang artinya ada pengaruh kadar hemoglobin pada hari-3 dan didapatkan $p>0,05$ yang artinya tidak ada pengaruh kadar hemoglobin pada hari-5.
\end{abstract}

\begin{abstract}
Hemoglobin levels are used as a requisite for determining blood transfusion therapy for patient's with anemia. Prior to blood transfusion it is initially stored in blood bags than contain CPDA-I antocoagulant with shelf life for 35 days at temperature $2-6^{\circ} \mathrm{C}$ with FIFO system. The purpose of this study was to determine hemoglobin levels in blood bags on the third dan fifth day of in increase the patient's hemoglobin level in Unit Donor Darah PMI Palangkaraya. The research was conducted with a descriptive method with a Linear Regression research design. The sample used is a whole blood bag of blood obtained by purposive sampling technique with a total sample is 30 blood bags. The paired Linear Regression on the while the whole blood bags obtained $p<0.05$ indicating that there was effet storage in hemoglobin levels on third day, and $p>0.05$ indicating that was no effect storage in hemoglobin levels on fifth day.
\end{abstract}

\section{PENDAHULUAN}

Donor darah adalah pemberian darah atau komponen darah dari satu individu (donor) ke individu lainnya (resipien), yang bertujuan untuk menggembalikan dan mempertahankan volume yang normal peredaran darah, meningkatkan oksigenasi jaringan serta memperbaiki fungsi hemostasis (Sudarmanto, 2010).

Sebelum dilakukan donor darah, perlu dilakukan seleksi donor darah dilakukan dengan tujuan untuk melindungi kesehatan donor dengan memastikan bahwa donasi tersebut tidak berbahaya bagi kesehatannya, dan melindungi pasien dari resiko penyakit menular atau efek merugikan lainnya. Bila calon donor diyakini sehat dan siap mendonorkan darahnya maka dilakukan pencatatan identitas, pemberian kode donor, pemeriksaan hemoglobin dan golongan darah merupakan aktivitas awal yang dilakukan sebelum kegiatan lain di Unit Donor Darah (Juliani, 2010).

Berdasarkan Penelitian Rusli (2013) syarat donor darah yang harus mempunyai kriteria seperti umur, berat badan, tekanan darah juga harus melihat hasil hemoglobin pendonor. Selain karakteristik pendonor perlu juga dilakukan pengecekan klinik darah meliputi kadar hemoglobin. Penelitian Ranchan dan 
Aditya (2013) pengecekan kadar hemoglobin sebelum donor di lakukan untuk mengetahui normal atau tidaknya kadar hemoglobin pada saat itu. Penelitian Rahmania (2017) apabila tidak dilakukan seleksi donor akan memiliki risiko tinggi seperti darah yang diperoleh merupakan darah yang mempunyai riwayat penyakit menular, kadar hemoglobin dibawah nilai normal, berat badan dibawah standar atau tekanan darah dibawah nilai normal, sehingga dapat menyebabkan terjadinya reaksi transfusi bahkan terjadi reaksi hemolitik termasuk menggigil, sakit kepala, sakit punggung, dispnea, sianosis, nyeri dada, dan hipotensi. Sehingga sangat penting dilakukan seleksi donor.

Berdasarkan Peraturan Menteri Kesehatan Republik Indonesia Nomor 91 Tahun 2015 Tentang Standar Pelayanan Transfusi Darah, bahwa pengecekan kadar hemoglobin tidak saja dilakukan pada seleksi donor namun juga pada saat darah donor disimpan. Berdasarkan hasil penelitian Susilowati (2017) darah yang disimpan selama berhari-hari akan mengalami perubahan kadar hemoglobin. Dalam hasil penelitiannya menunjukan bahwa terdapat hubungan yang signifikan antara lama penyimpanan darah donor terhadap kadar hemoglobin dimana semakin lama darah disimpan maka semakin meningkat kadar hemoglobinnya. Kantong darah donor harus disimpan dalam lemari pendingin (blood bank) pada suhu $2-6^{\circ} \mathrm{C}$ berdasarkan golongan darah dan masa kadaluarsa darah dengan sistem First In Fist Out (FIFO) yaitu suatu sistem yang mengatur pengeluaran darah dimana darah yang pertama kali masuk maka akan pertama kali dikeluarkan. Darah donor yang disimpan menggunakan antikoagulan Citrate Phosphat Dextrose (CPD) akan bertahan selama 21 hari sedangkan darah donor yang disimpan dengan antikoagulan Citrate Phospat Dextrose Adenine One (CPDA-I) akan betaha selama 35 hari setelah aftap (WHO, 2005).

Berdasarkan Pedoman Pelayanan Transfusi Darah, darah yang disimpan pada suhu yang tidak dianjurkan akan mengakibatkan kemampuan darah untuk menyalurkan oksigen menjadi berkurang. Penyimpanan darah sesuai dengan suhu $2-6^{\circ} \mathrm{C}$ dilakukan untuk mengurangi pertumbuhan bakteri yang mengkontaminasi darah yang disimpan. Penyimpanan pada suhu diatas $6^{\circ} \mathrm{C}$ menyebabkan pertumbuhan bakteri yang sangat cepat sehingga transfusi darah bisa berakibat fatal bagi penderita yang menerimanya. Batas penyimpanan $2^{\circ} \mathrm{C}$ juga sangat penting, karena sel darah merah sangat sensitif terhadap pembekuan. Apabila sel darah merah membeku, maka dinding sel darah akan pecah dan hemoglobin akan keluar (hemolisis).

Penelitian Sitanggang (20l8), menunjukan bahwa semakin lama darah disimpan maka semakin banyak sel darah merah yang hancur dan semakin kecil jumlah sel darah merah yang dapat bertahan hidup. Penelitian Naim (2014) darah yang disimpan terlalu lama akan mengalami pergeseran kurva disosiasi oksigen kearah kiri. Oksigen terikat kuat dengan hemoglobin dan terlalu sedikit yang diberikan kepada jaringan, sehingga sel eritrosit banyak yang lisis maka kemungkinan darah yang disimpan akan mengalami kenaikan kadar hemoglobin.

Relevan dengan penelitian Ranchman dan Aditya (2013) kadar hemoglobin yang terlalu tinggi, dapat mengakibatkan darah menjadi terlalu pekat atau kental, sehingga mengakibatkan menambahnya beban kerja jantung pada pasien penerima tranfusi sehingga hasilnya menjadi tidak optimal. Ranchman dan Aditya (2013) juga menyebutkan jika kadar hemoglobin kurang dari normal maka transportasi oksigen keseluruh tubuh akan terganggu.

Suminingsih (2017) dalam penelitiannya menunjukan adanya pengaruh lama simpan kantong darah donor suhu $2-6^{\circ} \mathrm{C}$ terhadap kadar hemoglobin. Rerata kadar hemoglobin kantong darah segar setelah aftaf 13,70 g/dl, sedangkan kadar hemoglobin kantong darah simpan suhu $2-6^{\circ} \mathrm{C}$ setelah satu minggu adalah 13,72 g/dl, sehingga dapat disimpulakan bahwa sesudah 
disimpan selama satu minggu sampel mengalami peningkatan kadar hemoglobin.

Berdasarkan observasi peneliti di Unit Donor Darah PMI kota Palangka Raya, proses penyimpanan kantong darah donor sudah dilakukan sesuai standar. Namun kantong darah donor tidak dilakukan pengecekan kadar hemoglobin setelah disimpan dan pada saat didistribusikan ke resipien sehingga tidak diketahui kadar hemoglobin pada kantong darah tersebut. Berdasarkan surat keterangan dari Unit Donor Darah PMI Kota Palangka Raya nomor 02I3/04.0I.02/UM/UTD.PKY/VI/2020 rata-rata penyimpana kantong darah minimal 3 hari dan maksimal 5 hari kantong sudah didistribusikan ke resipien, sehingga peneliti ingin melakukan penelitian pengecekan kadar hemoglobin pada hari pertma, hari ketiga dan hari kelima. Dari uraian tersebut peneliti ingin melalukan penelitian pengaruh lama penyimpanan kantong darah terhadap kadar hemoglobin pada komponen whole blood. Metode yang digunakan dalam penelitian ini yaitu menggunakan Hematology Analizer, karena merupakan Gold Standard dalam pemeriksaan kadar hemogloin darah.

\section{METODE PENELITIAN}

Penelitian ini menggunakan metode deskriptif, yaitu suatu metode penelitian yang bertujuan untuk mengambarkan atau mendeskripsikan tentang suatu keadaan secara objektif, lalu diuraikan. Penelitian ini bertujuan untuk mengetahui pengaruh lama penyimpanan kantong darah terhadap kadar hemoglobin pada komponen whole blood di Unit Donor Darah PMI Kota Palangka Raya. Penelitian pengaruh lama penyimpanan kantong darah terhadap kadar hemoglobin pada komponen whole blood di unit donor darah pmi kota Palangka Raya sampel yang digunakan adalah ampel darah Whole Blood yang didapatkan dari kantong darah donor yang ada di Unit Donor Darah Palang Merah Indonesia Kota Palangka Raya dengan jumlah 737 populasi. Besaran sampel yang dibutuhkan dalam penelitian ini sebanyak 384 sampel hasil dari perhitungan rumus Lemeshow. Teknik penarikan sampling menggunakan metode sampling jenuh. Sampel yang didapatkan dari pendonor setelah proses aftaf selesai, darah dihomogenkan dan disiler. Setelah itu dimasukan kedalam 3 tabung vacutainer tutup merah. Tabung pertama dilakukan pengukuran kadar hemoglobin di laboratroium Instrumen Universitas Muhammadiyah Palangkaraya. Tabung kedua disimpan di refrigerator pada suhu $2-6^{\circ} \mathrm{C}$ selama tiga hari. Tabung ketiga disimpan di refrigerator pada suhu 2$6^{\circ} \mathrm{C}$ selama lima hari.

Data yang diperoleh dari penelitian, selanjutnya dilakukan uji kenormalan data dengan menggunakn uji Shapiro-Wilk karena sampel yang digunakan <50. Data yang dihasilkan terdistribusi normal selanjutnya dilakukan pengujian menggunakan uji Regression Linear Test.

\section{HASIL DAN PEMBAHASAN HASIL}

Hasil Penelitian menunjukan bahwa kadar hemoglobin pada komponen whole blood yang disimpan di refrigerator dengan suhu $2-6^{\circ} \mathrm{C}$ mengalami kenaikan pada hari ketiga dan kelima.

Kantong darah donor yang diteliti berjumlah 30 kantong yang terdiri dari 8 kantong darah golongan darah A, 14 kantong darah golongan darah B, 4 kantong darah golongan darah $\mathrm{O}$ dan 4 kantong darah golongan darah $\mathrm{AB}$. Pemeriksaan kadar Hemoglobin dilakukan di Laboratorium Instrument Universitas Muhammadiyah Palangkaraya. Metode yang digunakan dalam pemeriksaan kadar hemoglobin yaitu menggunakan Hematology Analizer, karena merupakan Gold Standard dalam pemeriksaan kadar hemogloin darah. Durasi waktu yang diperiksa yaitu waktu pertama kali darah donor diambil, kemudian hari ketiga dan hari kelima. Durasi waktu penelitian dilakukan berdasarkan rata-rata penyimpanan kantong darah di Unit Donor Darah Palang Merah Indonesia Kota 
Palangka Raya dimana penyimpanan minimal 3 hari dan maksimal 5 hari darah sudah didistribusikan ke pasien. Adapun karakteristik responden dapat dilihat pada Tabel I berikut:

Tabel I. Karakteristik Responden Di Unit Donor Darah PMI Kota Palangka Raya Tahun 2020

\begin{tabular}{|c|c|c|}
\hline \multirow[t]{2}{*}{ Karakteristik } & \multicolumn{2}{|c|}{$\begin{array}{c}\text { Frekuensi } \\
\mathrm{n}=30\end{array}$} \\
\hline & Jumlah (n) & $\begin{array}{c}\text { Persentase } \\
(\%)\end{array}$ \\
\hline \multicolumn{3}{|l|}{ Usia : } \\
\hline $17-19$ tahun & 0 & 0 \\
\hline 20-29 tahun & 16 & 53,33 \\
\hline 30-39 tahun & 8 & 26,67 \\
\hline 40-50 tahun & 6 & 20 \\
\hline \multicolumn{3}{|l|}{ Jenis Kelamin : } \\
\hline Laki-laki & 26 & 86,67 \\
\hline Perempuan & 4 & 13,33 \\
\hline \multicolumn{3}{|l|}{ Golongan Darah : } \\
\hline A & 8 & 26,67 \\
\hline$B$ & 14 & 46,67 \\
\hline 0 & 4 & 13,33 \\
\hline$A B$ & 4 & 13,33 \\
\hline
\end{tabular}

Sumber : Data Primer, 2020

Tabel I menunjukan bahwa sebagian besar responden berusia 20-29 tahun (53,33\%), berjenis kelamin laki-laki $(86,67 \%)$ dan bergolongan darah B (46,67\%). Kelompok usia 20-29 merupakan usia produktif sehingga banyak pendonor dari kelompok usia tersebut. Pendonor mayoritas adalah laki-laki dikarena perempuan yang cenderung tidak memenuhi syarat donor seperti hemoglobin yang rendah.

Adapun gambaran kadar hemoglobin dapat dilihat pada Tabel 2 berikut ini.

Tabel 2. Rata-Rata Dan Estimasi Pengukuran Kadar Hemoglobin Pada Sampel

\begin{tabular}{llllll}
\hline & & & & \multicolumn{2}{c}{$95 \% \mathbf{C l}$} \\
\cline { 3 - 5 } & & & & Lower & Upper \\
\hline Hari ke-I & II,0 & 15,9 & $13, I$ & & \\
Hari ke-3 & $11, I$ & 16,0 & 13,3 & 0,337 & 1,206 \\
Hari ke-5 & 11,2 & 16,1 & 13,4 & $-0,393$ & $0,44 I$ \\
\hline
\end{tabular}

Tabel 2 menunjukan bahwa pada pemeriksaan

kadar hemoglobin pada hari pertama, kadar hemoglobin terendah $1 \mathrm{I}, 0 \mathrm{~g} / \mathrm{dL}$ dan kadar hemoglobin tertinggi $15,9 \mathrm{~g} / \mathrm{dL}$ dengan rata-rata $13,1 \mathrm{~g} / \mathrm{dL}$. Setelah disimpan selama 3 hari sebagian besar kantong darah megalami peningkatan kadar hemoglobin dengan kadar hemoglobin terendah $\mathrm{I} \mathrm{I}, \mathrm{I} \mathrm{g} / \mathrm{dL}$ dan kadar hemoglobin tertinggi $16,0 \mathrm{~g} / \mathrm{dL}$ dengan rata-rata $13,3 \mathrm{~g} / \mathrm{dL}$. Begitupun setelah disimpan selama 5 hari sebagian besar kantong darah megalami peningkatan kadar hemoglobin dengan kadar hemoglobin terendah II,2 g/dL dan kadar hemoglobin tertinggi 16,1 g/dL dengan rata-rata $13,4 \mathrm{~g} / \mathrm{dL}$.

Adapun gambaran kadar hemoglobindapat dilihat pada gambar I berikut:

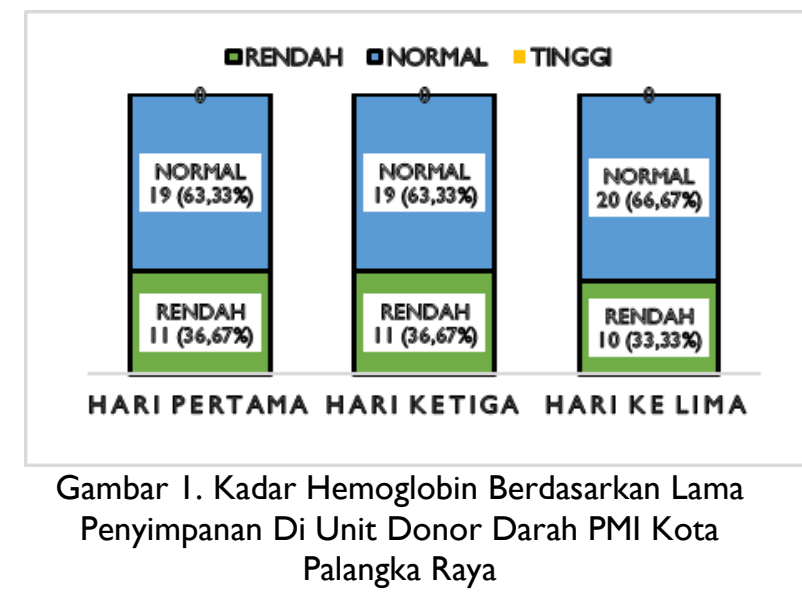

Gambar I menunjukan bahwa pada hari pertama terdapat II (36,67\%) sampel dengan kadar hemoglobin rendah, terdapat 19 (63,33\%) sampel dengan kadar hemoglobin normal dan tidak terdapat responden dengan kadar hemoglobin tinggi. Berdasarkan Peraturan Menteri Kesehatan Republik Indonesia Nomor 9I Tahun 2015 Tentang Standar Pelayanan Transfusi Darah calon pendonor harus memenuhi syarat kadar hemoglobin 12,5 hingga $17,0 \mathrm{~g} / \mathrm{dL}$. Berdasarkan hasil penelitian bahwa terdapat 36,67\% sampel dengan kadar hemoglobin rendah. Hal ini dimungkinkan karena perbedaan metode pengukuran kadar hemoglobin yang digunakan oleh peneliti dan Unit Donor Darah PMI Kota Palangkaraya, dimana peneliti menggunakan hematology analyzer sedangkan Unit Donor Darah PMI Kota Palangkaraya menggunakan CuSO4. Metode CuSO4 adalah test kualitatif berdasarkan berat jenis. Darah donor turun ke dalam larutan tembaga sulfat ( $C u$-sulfat) dan terbungkus dalam kantong tembaga proteinate yang 
mencegah setiap perubahan dalam berat jenis sekirat 15 detik. Jika hemoglobin sama dengan atau lebih $12,5 \mathrm{gr} / \mathrm{dl}$ maka akan tenggelam dalam waktu 15 detik, yang berarti donor dapat diterima (Kiswari, 2014). Sehingga metode ini memiliki keterbatasan pengukuran dan tidak akurat dalam pemeriksaan kadar hemoglobin. Penelitian Ranchan dan Aditya (2013) pengecekan kadar hemoglobin sebelum donor di lakukan untuk mengetahui normal atau tidaknya kadar hemoglobin pada saat itu. Namun pengecekan menggunakan metode CuSO4 ini kurang akurat. Hasil penelitian ini, peneliti menemukan $36,67 \%$ pendonor yang masih memiliki kadar hemoglobin rendah yang mana metode CuSo4 ini tidak layak digunakan untuk pengecekan hemoglobin, sedangkan metode hematology analyzer adalah metode Gold Standard dalam pemeriksaan kadar hemogloin darah, yg mna mungkin bisa dipertimbangkan metode yang digunakan untuk pengecekan kadar hemoglobin calon donor dalam periode selanjutnya. Setelah kantong darah disimpan selama 3 hari terdapat sampel dengan kadar hemoglobin rendah sebanyak II (36,67\%), terdapat responden dengan kadar hemoglobin normal sebanyak $19(63,33 \%)$ dan tidak terdapat responden dengan kadar hemoglobin tinggi. Setelah kantong darah disimpan 5 hari terdapat sampel dengan kadar hemoglobin rendah 10 (33,33\%), terdapat responden dengan kadar hemoglobin normal sebanyak 20 $(66,67 \%)$ dan tidak terdapat responden dengan kadar hemoglobin tinggi.

Berdasarkan Peraturan Menteri Kesehatan Republik Indonesia Nomor 91 Tahun 2015 Tentang Standar Pelayanan Transfusi Darah, bahwa pengecekan kadar hemoglobin tidak saja dilakukan pada seleksi donor namun juga pada saat darah donor disimpan. Namun hal yang ditemukan oleh peneliti adalah instansi terkait tidak melakukan pengecekan kadar hemoglobin pada kantong darah yang sudah disimpan dan saat akan didistribusikan ke resipien.
Adapun pengaruh lama penyimpanan terhadap kadar hemoglobin dapat dilihat pada Tabel 3 berikut.

Tabel 3. Pengaruh lama penyimpanan kantong darah terhadap kadar hemoglobin di Unit Donor Darah PMI Kota Palangka Raya

\begin{tabular}{|c|c|c|c|c|c|c|}
\hline \multirow{2}{*}{$\begin{array}{c}\text { Pengaru } \\
\text { h Waktu } \\
\text { Penyimp } \\
\text { anan }\end{array}$} & \multirow{2}{*}{$\begin{array}{l}\text { Nor } \\
\text { mal }\end{array}$} & \multirow{2}{*}{$\begin{array}{c}\text { Rend } \\
\text { ah }\end{array}$} & \multirow{2}{*}{$\mathbf{t}$} & \multirow{2}{*}{$\begin{array}{c}\mathbf{P} \\
\text { Val } \\
\text { ue }\end{array}$} & \multicolumn{2}{|c|}{$95 \% \mathrm{Cl}$} \\
\hline & & & & & $\begin{array}{c}\text { Lo } \\
\text { wer }\end{array}$ & $\begin{array}{l}\text { Up } \\
\text { per }\end{array}$ \\
\hline Hari & & & 3,6 & 0,00 & 0,33 & 1,20 \\
\hline Ketiga & 19 & II & 42 & 1 & $\begin{array}{l}7 \\
-\end{array}$ & 6 \\
\hline $\begin{array}{c}\text { Hari } \\
\text { Kelima }\end{array}$ & 20 & 10 & $\begin{array}{l}0,1 \\
20\end{array}$ & $\begin{array}{c}0,90 \\
6\end{array}$ & $\begin{array}{c}0,39 \\
3\end{array}$ & $\begin{array}{c}0,44 \\
I\end{array}$ \\
\hline
\end{tabular}

Sumber : Data Primer, 2020

Tabel 3 menunjukan hasil output Regression Linear Test dari hasil olah data SPSS. Menurut Santoso (2014) pedoman atau dasar pengambilan keputusan dalam uji Regression Linear dapat dilakukan dengan cara melihat nilai tabel output Regression Linear Test dari hasil olah data SPSS. Pengambilan keputusan untuk uji ini dilakukan dengan membandingkan antara nilai Sig. dengan batas kritis yakni 0.05 .

Berdasarkan tabel 3 dapat dilihat bahwa rata-rata peningkatan kadar hemoglobin pada hari ketiga yaitu paling rendah $0,3 \mathrm{~g} / \mathrm{dL}$ dan rata-rata peningkatan tertinggi pada hari ketiga yaitu I,2 g/dL. Begitupun pada hari kelima dapat dilihat bahwa rata-rata peningkatan kadar hemoglobin pada hari ketiga yaitu paling rendah $0,3 \mathrm{~g} / \mathrm{dL}$ dan rata-rata peningkatan tertinggi pada hari ketiga yaitu 0,4 g/dL.

Berdasarkan tabel 3 pengaruh penyimpanan pada hari ketiga diketahui bahwa nilai $P$ Value $<0,05$. Dengan demikian dapat dikatakan ada pengaruh penyimpanan kantong darah donor pada hari ketiga terhadap kadar hemoglobin pada komponen whole blood. Berdasarkan Tabel 3 pengaruh penyimpanan pada hari kelima diketahui bahwa nilai $P$ Value $>0,05$. Dengan demikian dapat dikatakan tidak ada pengaruh penyimpanan kantong darah donor pada hari kelima terhadap kadar hemoglobin pada komponen whole blood.

Pada hari ketiga dikatakan bahwa terdapat pengaruh penyimpanan kantong darah. Hal ini dikarenakan adanya perubahan kadar hemoglobin pada kantong 
darah yang disimpan selama 3 hari dalam refrigerator. Perubahn kadar hemoglobin pada kantong darah terjadi dikarenakan efek penyimpanan. Menurut Setyati (2010) Kerugiaannya darah simpan ialah faktor pembekuan terutama faktor $\mathrm{V}$ dan VIII sudah habis, kemampuan transportasi oksigen oleh eritrosit menurun disebabkan afinitas hemoglobin terhadap oksigen yang tinggi, sehingga oksigen sukar dilepas ke jaringan. Hal ini disebabkan penurunan kadar 2,3 DPG, kadar kalium, amonia dan asam laktat tinggi (Setyati, 2010). Menurut Naim (2014) pada masa penyimpanan darah akan mengalami perubahan perubahan komponen darah terutama eritrosit akan mengalami perubahan bentuk yang cukup bermakna seiring lamanya waktu penyimpanan darah. Efek penyimpanan darah akan membuat eritrosit banyak yang mati segera setelah darah ditranfusikan karena terjadi penurunan kadar ATP (Adenosin Tri Phospat). Setelah darah disimpan selama beberapa hari akan mengalami pergeseran kurva disosiasi Oksigen kearah kiri. Oksigen terikat kuat dengan hemoglobin dan terlalu sedikit yang diberikan kepada jaringan. Karena sel eritrosit banyak yang lisis maka kemungkinan darah yang disimpan akan mengalami kenaikan kadar hemoglobin. Trombosit akan hilang fungsinya setelah I hari darah disimpan, juga faktor-faktor pembeku darah (FV dan FVIII) (Naim, 20I4).

Berdasarkan pada tebel 3 dapat dilihat bahwa pada hari kelima dikatakan bahwa tidak terdapat pengaruh penyimpanan kantong darah selama lima hari terhadap kadar hemoglobin ditunjukan dengan nilai rata-rata peningkatan kadar hemoglobin pada hari kelima -0,3 g/dL. Hal ini dikarenakan kadar hemoglobin pada hari kelima tidak terjadi peningkatan kadar hemoglobin yang signifikan. Berdasarkan penelitian pada hari kelima menunjukan bahwa terjadi peningkatan pada kadar hemoglobin namun secara statistik hal ini diketahui tidak bermakna dan tidak ada pengaruh penyimpanan selama penyimpanan lima hari.

\section{KESIMPULAN}

Penelitian menunjukan bahwa adanya pengaruh penyimpanan pada hari ketiga, sedangkan hasil penelitian pada hari kelima meski terjadi peningkatan pada kadar hemoglobin namun secara statistik hal ini diketahui tidak bermakna selama penyimpanan. Berdasarkan hasil tersebut dapat disimpulkan bahwa pada hari ketiga terdapat pengaruh penyimpanan dan tidak ada pengaruh penyimpanan kantong darah donor pada hari kelima terhadap kadar hemoglobin pada komponen whole blood. Bagi peneliti selanjutnya disarankan untuk meneliti pada variable yang lainnya.

\section{DAFTAR PUSTAKA}

Kiswari, R., 2014. Hematologi dan Transfusi. Jakarta : Penerbit Erlangga.

Naid, T., Arwie, D., \& Mangerangi, F. 2012. Pengaruh Waktu Penyimpanan Terhadap Jumlah Eritrosit Darah Donor. As-Syifaa Jurnal Farmasi, 4(I), II2120.

Naim, N. 2014. Pengaruh lama penyimpanan darah donor terhadap hasil pemeriksaan trombosit, eritrosit dan hemoglobin pada unit transfusi darah rumah sakit umum lasinrang kabupaten pinrang. Media Analis Kesehatan Vol. V No.I

Peraturan Menteri Kesehatan Republik Indonesia Nomor 9I Tahun 2015 Tentang Standar Pelayanan Transfusi Darah.

Permono, B, Sutaryo, Ugrasena, Windiasturi, E, Abdulsalam, M, Haroen, H. 20l0. Buku Ajar Hematologi - Onkologi Anak, Cetakan ketiga. Penerbit Badan Penerbit IDAI. Jakarta.

Saidjao, Y. 2019. Pengaruh Lama Penyimpanan Terhadap Kadar Hemoglobin Pada Kantong Darah Donor Di Bank Darah Rumah Sakit Santa Maria Pekanbaru. Jurnal Sains dan Teknologi Laboratorium Medik, 4(2), 32-38.

Setyati Julia, Soemantri Ag, 2010. Tranfusi Darah Yang Rasional. Pelita Insani ; 19-21,69

Sitanggang, N. M. A. 2019. Pengaruh Penyimpanan Darah Terhadap Kadar Hemoglobin Pada Komponen Whole Blood Darah Donor Sebelum Dan Sesudah Disimpan Selama Satu Minggu Di Pmi Kota Medan. KTI. Politeknik Kesehatan Kemenkes RI Medan, Medan. 
Suminingsih. 2017. Pengaruh Lama Simpan Kantong Darah Donor Pada Suhu $2^{\circ}-6^{\circ} \mathrm{C}$ Terhadap Kadar Hemoglobin Sebelum Transfusi Darah. Undergraduate Thesis. Universitas Muhammadiyah Semarang.

Susilowati. 2017. Hubungan Lama Waktu Penyimpanan Darah Donor Terhadap Kadar Hemoglobin. 2017.

Syaifudin. 2016. Metode Penelitian. Yogyakarta : Pustaka Pelajar.

Viveronika. 2017. Pengaruh Transfusi Packed Red Cell Dan Whole Blood Terhadap Kadar Hemoglobin. Undergraduate Thesis. Universitas Muhammadiyah Semarang.

WHO, 2005. Manual On The Management, Maintenance and Use of Blood Cold Chain Equipment. Safe blood and blood product. 